\title{
Quality Improvement of Used Cooking Oil by Using Nanocellulose from Sugarcane Bagasse as Adsorbent
}

\author{
Winda Trisna Wulandari ${ }^{* *}$, Rosmaya Dewi ${ }^{1}$ \\ 'Pharmacy Department, STIKes Bakti Tunas Husada, Tasikmalaya, Indonesia \\ *Corresponding author email: windatrisna@stikes-bth.ac.id
}

Received: 9 Dec 2018; Accepted: 28 May 2019; Available online: 5 Jun 2019

\begin{abstract}
Frying oil can produce substances that are harmful for health. One way that can be used to eliminate these dangerous compounds is by using adsorbent. Recently, many adsorbents from natural fibers have been developed. One of them is cellulose which contains $40-50 \%$ in bagasse. Nano sized cellulose or called by nanocellulose is reported have better properties than cellulose. So, this research is aimed to utilize nanocellulose from sugarcane bagasse as adsorbent for used cooking oil. Cellulose produced from bagasse is hydrolyzed using $50 \% \mathrm{H}_{2} \mathrm{SO}_{4}$ at $40{ }^{\circ} \mathrm{C}$ for 10 minutes. Used cooking oil soaked with nanocellulose for 1×24 hour, $2 \times 24$ hours and $3 \times 24$ hours. Then, the quality of used cooking oil was tested through organoleptic, acid number, peroxide number and water content test. Nanocellulose produced from hydrolysis process by using acid has a particle size distribution in nanometer range, with $95.3 \%$ having a particle size of $437.5 \mathrm{~nm}$. Immersion of cooking oil by nanocellulose for $2 \times 24$ hours can reduce the value of free fatty acids until $18.01 \%$, the peroxide number decreases by $57.69 \%$ and the water content decreases to $99.99 \%$ even though organoleptic changes are not very noticeable. Based on this results, nanocellulose has high potential to be used as adsorbent in used cooking oil.
\end{abstract}

Keywords: nanocellulose, sugarcane, bagasse, adsorbent, used cooking oil

\section{INTRODUCTION}

The high price of cooking oil on the market makes people, especially food traders, use used cooking oil as a frying medium. The result of Suroso's research (2013) shows that used cooking oil does not meet the requirements of the Indonesian National Standard (SNI) in terms of peroxide numbers, acid numbers and water content. In addition, the use of used cooking oil also causes various problems, especially in the health sector. Heating of cooking oil at high temperatures can cause polymerization, hydrolysis and oxidation which can produce toxic compounds such as alcohol, aldehydes, aromatic hydrocarbons and acrolin. The compounds produced can cause increased intracellular peroxide, DNA damage, rapid cell spread and release of proinflammatory cytokines associated with increased genotoxicity and tumors (Peng, Lan, Lin, \& Kuo, 2017)

Histopathological observations showed that experimental animals given cooking oil with 3 repetitions of heating suffered significant damage in jejunum, large intestine and liver. In addition, there is an adaptive oxidative response. Changes at enzyme levels are caused by the formation of Reactive Oxygen Species (ROS) through automatic oxidation or enzymes that catalyze the oxidation of electrophilic components in used cooking oil. Analysis of blood samples showed an increase in glucose, creatinine and cholesterol levels and a decrease in protein and albumin levels in a group of test animals that were given repeatedly heated cooking oil. Thus, thermal oxidation of cooking oil produces free radicals and produces detrimental effects on health (Venkata \& Subramanyam, 2016)

The most recommended physical and chemical method in the process of refining used cooking oil is the use of adsorbents (Teleken, 2016). Lately, adsorbents from natural fibers are being developed. In addition to its abundant availability and relatively cheap price, adsorbents from natural fiber also have biodegradable properties or easily degraded naturally so it is expected that the waste produced is not harmful to the community and the surrounding environment (Olivera et al., 2016). Natural fibers which is the most abundance in nature is cellulose. Cellulose can be easily found in all plants, one of which can be obtained from bagasse which has a cellulose content of $40-50 \%$, hemicellulose $23-35 \%$ and lignin of $18-24 \%$ (Mandal \& Chakrabarty, 2011).

Cellulose in nano size or commonly called nanocellulose is a material that is being developed. This is because nanocellulose has good mechanical properties, high crystallinity values until 50-90\% and has a large surface area (Cho \& Park, 2011; Mandal \& Chakrabarty, 2014). Because of its unique nature, nanocellulose is widely used in various applications including nanocomposite to improve the mechanical properties of a material as well as being used in biomedical applications and drugs. The role of nanocellulose as an adsorbent has also been widely developed including adsorbents for heavy metals and dyes in solution or wastewater (Olivera et al., 2016). Until now, the use of nanocellulose as an adsorbent for used cooking oil has still not been developed even 
though the bagasse itself has potential to be used as an adsorbent. The study of Ramdja, Febrina, and Krisdianto (2010) shows that soaking bagasse for $2 \times 24$ hours can reduce water content as much as $0.0050 \%$ and adsorb free fatty acids until $0.0999 \%$. Therefore, this study aims to utilize nanocellulose from bagasse as an adsorbent in used cooking oil.

\section{EXPERIMENTAL SECTION}

\section{Materials}

The sugarcane bagasse was obtained from Tasikmalaya, West Java, Indonesia. The used cooking oil was obtained from food trader in Tasikmalaya, Indonesia. Analytical grade of $\mathrm{NaOCl}, \mathrm{NaOH}, \mathrm{H}_{2} \mathrm{SO}_{4}$, ethanol, phenolphthalein, $\mathrm{KOH}$, acetic acid glacial, isooctane, $\mathrm{KI}$, $\mathrm{Na}_{2} \mathrm{~S}_{2} \mathrm{O}_{3}, \mathrm{KIO}_{3}, \mathrm{HCl}$, amylum, $\mathrm{K}_{2} \mathrm{Cr}_{2} \mathrm{O}_{7}$ were obtained from Merck, Tbk.

\section{Instrumentations}

FTIR Spectrometer (Simadzu) used to identification functional group of nanocellulose, PSA Beckman Coulter Delsa $^{\mathrm{TM}}$ used to identification particle distribution of nanocellulose produced.

\section{Preparation of Sugarcane Bagasse}

Sugarcane bagasse is taken from sugar cane water waste in Tasikmalaya, West Java, Indonesia. The bagasse is dried, then milled until become powder.

\section{Extraction of Cellulose}

Lignin removal (delignification) is done by adding 250 $\mathrm{mL}$ of $0.735 \% \mathrm{NaOCl}$ to 15 grams of bagasse in a round bottom flask. The mixture was refluxed for 6 hours with constant stirring of $350 \mathrm{rpm}$ at $45^{\circ} \mathrm{C}$. The reflux is filtered using a vacuum filterand rinsed with water until become neutral. The residue from previous process was mixed with $150 \mathrm{~mL}$ of $17.5 \% \mathrm{NaOH}$ and refluxed for 3 hours with constant stirring of $350 \mathrm{rpm}$ at $45{ }^{\circ} \mathrm{C}$ to remove hemicellulose. The result of reflux is filtered and rinsed until neutral. Then, residue obtained is dried in room temperature.

\section{Synthesis of Nanocellulose}

Cellulose that has been produced from previous process is hydrolyzed with $50 \%$ of $\mathrm{H}_{2} \mathrm{SO}_{4}$ with a ratio of $1: 25$ $(\mathrm{w} / \mathrm{v})$. This hydrolysis is carried out for 10 minutes at 40 ${ }^{0} \mathrm{C}$ and stopped by diluting 10 times with the addition of aqua $\mathrm{dm}$. The resulting colloid is centrifuged at a speed of $6500 \mathrm{rpm}$ for 30 minutes. The precipitate is washed and dialyzed $\mathrm{d}=$ for 5 days to neutralize and remove sulphate ion. Neutral colloid is sonicated for 10 minutes in order to homogenize the nanocellulose produced (Wulandari, Rochliadi, \& Arcana, 2016).

\section{Use of Nanocellulose as an adsorbent for Used Cooking Oil}

Nanocellulose as much as $100 \mathrm{mg}$ is put into $100 \mathrm{~mL}$ of used cooking oil and soaked for $1 \times 24,2 \times 24$ and $3 \times 24$ hours then it is filtered. The qualities of filtrate (organoleptic, water content, free fatty acid and peroxide number) were analyzed by following Indonesian National Standard (SNI) SNI 7709:2012 and SNI 3741:2013.

\section{Organoleptic Test}

Cooking oil to be analysed is placed on a clean and dry glass. Then, observed the colour, smelled the smell and tested with a sense of taste at least by 3 panellists.

\section{Water Content}

The porcelain saucer and lid were heated in oven at $130 \pm 1{ }^{\circ} \mathrm{C}$ for approximately 30 minutes and cooled in desiccator for 20-30 minutes, then weighed with an analytical balance $\left(\mathrm{W}_{\mathrm{o}}\right)$. After that, $2 \mathrm{~g}$ samples are inserted, closed and weighed $\left(\mathrm{W}_{1}\right)$. Then, it was heated by placing the lid on the side of dish in the oven at $130 \pm 1^{\circ} \mathrm{C}$ for 30 minutes. When it was finished, the cup is closed while still in the oven and transferred immediately into desiccator and cooled for 20-30 minutes until temperature is equal to the room temperature and then weighed $\left(\mathrm{W}_{2}\right)$.

Water content $(\%)=\frac{\mathrm{W} 1-\mathrm{W} 2}{\mathrm{~W} 1-\mathrm{W} 0} \times 100 \%$

W0 is the weight of the empty plate and the lid (g)

W1 is the weight of the dish, the lid and the sample before drying $(\mathrm{g})$

W2 is the weight of the dish, the lid and the sample after drying $(\mathrm{g})$

\section{Free Fatty Acid}

A total of $10 \mathrm{~g}$ sample was inserted into Erlenmeyer and dissolved with $50 \mathrm{~mL}$ of warm ethanol and added 5 drops of phenolphthalein as an indicator. Then, the solution is titrated with $0.1 \mathrm{~N}$ of $\mathrm{NaOH}$ until a pink color is formed. The required volume of $\mathrm{NaOH}$ solution was recorded. Free fatty acids/acid numbers are calculated as palmitic acid with the following calculations:

Free fatty acid (as palmitic acid) $=\frac{25,6 \times \mathrm{VXN}}{\mathrm{W}}$

$\mathrm{V}$ is the volume of $\mathrm{NaOH}$ solution needed, in $\mathrm{mL}$

$\mathrm{N}$ is the normality of $\mathrm{NaOH}$ solution, in Normality (N)

$\mathrm{W}$ is the weight of the test sample, in gram $(\mathrm{g})$

\section{Peroxide Number}

A total of $5 \mathrm{~g}$ sample was weighed, then put into dry Erlenmeyer. Then $50 \mathrm{~mL}$ of glacial acetic acid and isooctane was added (3:2). Erlenmeyer is closed and stirred until the solution is homogenous. After that, $0.5 \mathrm{~mL}$ of saturated potassium iodide was added and shaken for 1 minute. Then, $30 \mathrm{~mL}$ of distilled water were added immediately. Then, the solution was shaken and titrated with $\mathrm{Na}_{2} \mathrm{~S}_{2} \mathrm{O}_{3} 0.1 \mathrm{~N}$ until the yellow color was almost gone and then $0.5 \mathrm{~mL}$ starch indicator was added and titration continued. The solution must be shaken strongly to release all the iodine from the solvent layer until blue color disappears.

Peroxide Number $\left(\mathrm{mek} \mathrm{O}_{2} / \mathrm{kg}\right)=\frac{1000 \times n N \times(V 0-V 1)}{W}$

$\mathrm{N}$ is normality of $\mathrm{Na}_{2} \mathrm{~S}_{2} \mathrm{O}_{3}$ standard solution $(\mathrm{N})$ $\mathrm{V} 0$ is volume of $\mathrm{Na}_{2} \mathrm{~S}_{2} \mathrm{O}_{3}$ required for sample $(\mathrm{mL})$

$\mathrm{V} 1$ is volume of $\mathrm{Na}_{2} \mathrm{~S}_{2} \mathrm{O}_{3}$ required for blank (mL) 


\section{RESULTS AND DISCUSSION}

The FTIR spectrum of nanocellulose synthesized from bagasse is shown in Figure 1. The absorption peak at 3451 $\mathrm{cm}^{-1}$ is strain vibration for $\mathrm{OH}$ group, whereas at wave number of $2899 \mathrm{~cm}^{-1}$ is absorption for $\mathrm{CH}$ group. Absorption at $1644 \mathrm{~cm}^{-1}$ is reported as an $\mathrm{OH}$ vibration from absorbed water. The peak at $1382 \mathrm{~cm}^{-1}$ is peak for $\mathrm{CH}$ and $\mathrm{CO}$ groups found in polysaccharide ring in nanocellulose. Vibration of the COC group on the pyranose ring is shown by absorption at $1060 \mathrm{~cm}^{-1}(\mathrm{Li}$, Yue, \& Liu, 2012; Mandal \& Chakrabarty, 2011). From the FTIR spectrum, it can be concluded that hydrolysis process does not change the functional groups of cellulose. Cellulose produced from bagasse is reduced in size by hydrolysis using acid. This research uses sulfuric acid as its hydrolysis. Characterization of particle size is intended to determine whether the hydrolysis process has succeeded in producing nanocellulose. Figure 2 shows distribution size of nanocellulose based on PSA result.

Based on Figure 2 it can be seen that $100 \%$ of nanocellulose produced has the size below $1000 \mathrm{~nm}$ even below the size of $500 \mathrm{~nm}$. As many as $95.3 \%$ of nanocellulose are in the size of $437.5 \mathrm{~nm}$ while the rest $(4.7 \%)$ are in sizes 32.97 and $70.38 \mathrm{~nm}$. This shows that the hydrolysis of cellulose using acid has succeeded in producing nanometer-sized cellulose, also known as nanocellulose. The resulting nanocellulose is used as an adsorbent in used cooking oil. The quality of used cooking oil was tested through organoleptic test, moisture content and evaporating material, free fatty acid content or acid number and peroxide number.

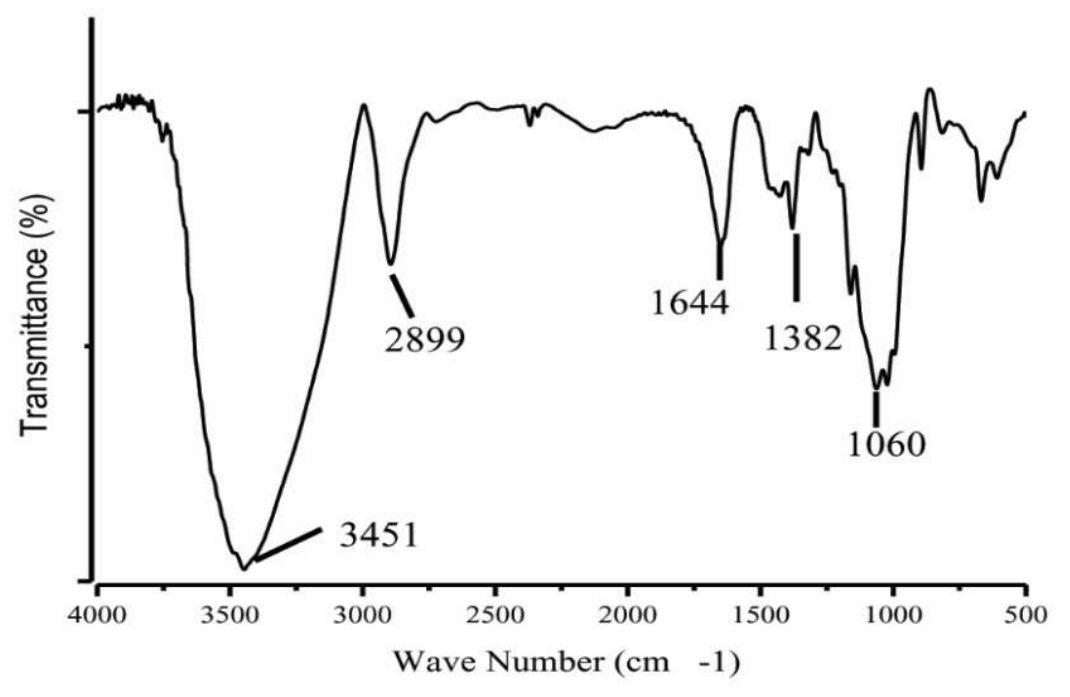

Figure 1. FTIR Spectrum of Nanocellulose

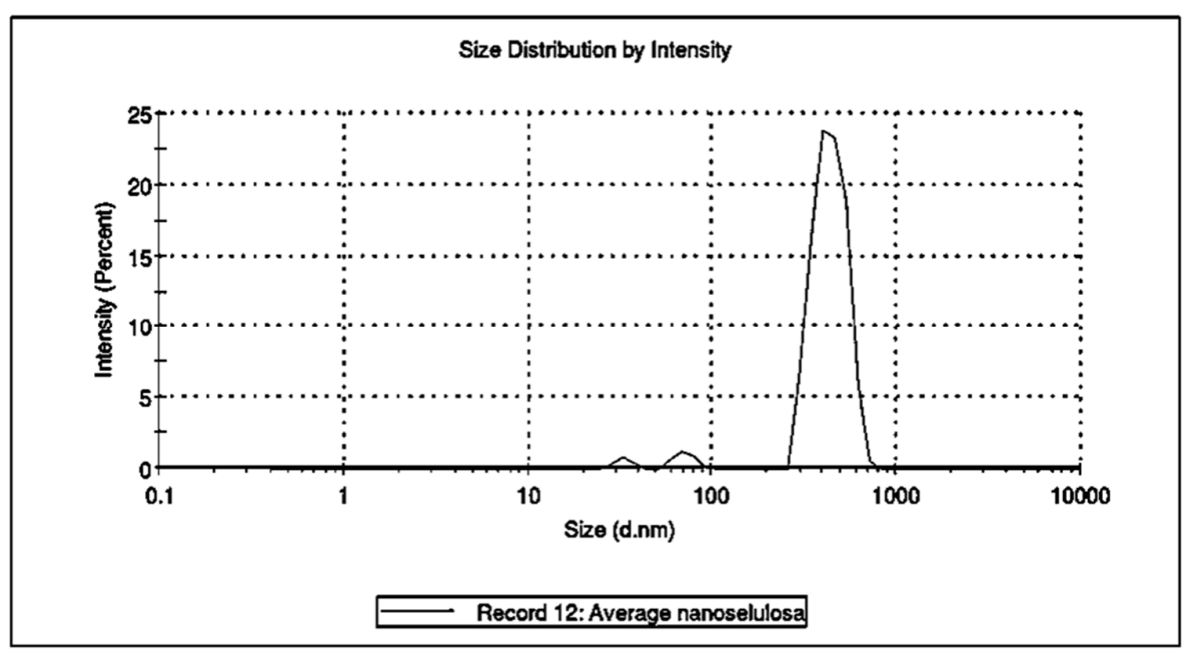

Figure 2. Particle Size Distribution of Nanocellulose 


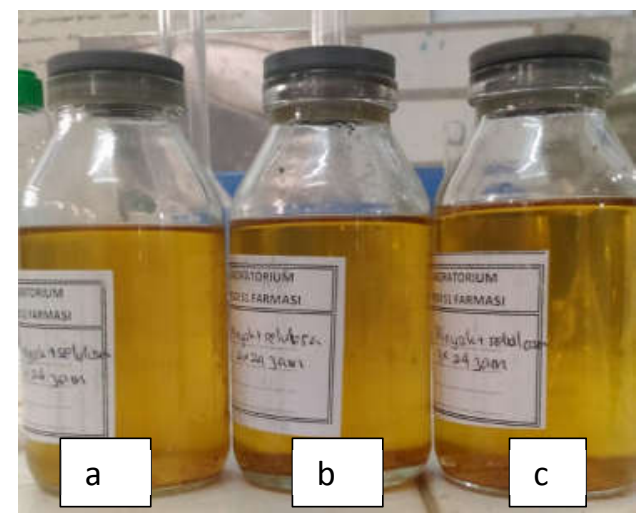

Figure 3. Used Cooking Oil after Immersion by Using Nanocellulose (a) 1 x 24 hours (b) 2 x 24 hours (c) 3 x 24 hours

\section{Organoleptic Test}

Based on the organoleptic test, used cooking oil before and after immersion are no different in terms of color, smell and taste. Used cooking oil that has been soaked by nanocellulose can be seen in Figure 3.

\section{Moisture and Volatile Material Content}

The result of testing moisture content and evaporating material can be seen in Figure 4. High water content can cause rancidity in used cooking oil. Soaking cooking oil with nanocellulose for $2 \times 24$ hours can reduce water content by almost $100 \%$, namely $99 \%$. This result is not good as cellulose which actually increases water content by $45.29 \%$ (Wulandari \& Dewi, 2018). The use of nanocellulose as an adsorbent can eliminate almost all water contained in cooking oil so that rancidity can be avoided. Nanocellulose has $-\mathrm{OH}$ group which is polar group, it can bind to water contained in used frying oil. Soaking with nanocellulose for $3 \times 24$ hours actually increases the water content of used cooking oil. This shows that the bond or interaction that occurs between nanocellulose and water is not too strong so that at a longer immersion the water can be released again and cause the value to increase.
Based on Indonesian National Standard (SNI) regarding the quality requirements of cooking oil, the water content and evaporating material in cooking oil should not exceed $0.1 \%$. Before immersion with nanocellulose, used cooking oil does not fulfill these requirement, but after immersion with nanocellulose for $1 \times 24$ hours and $2 \times 24$ hours the used frying oil fulfill the standards for reuse.

\section{Free Fatty Acid/Acid Number}

Free Fatty acids, even though in small amounts, can cause unpleasant taste. This applies to fats containing fatty acids that cannot evaporate, with $\mathrm{C}$ atoms greater than 14 . Free fatty acids that can evaporate with carbon atoms 4,6 , 8 and 10 produce a rancid odor and bad taste in food (Ketaren, S., 2012). Free fatty acid tested in used cooking oil is palmitic acid. Based on the result of free fatty acid test, immersion with nanocellulose for $2 \times 24$ hours can reduce acid number to $18.01 \%$. The decreasing of acid number is not significance, it is because cellulose has polar groups however fatty acid is nonpolar, so nanocellulose cannot adsorb fatty acid in used cooking oil completely. The results can be seen in Figure 5.

\section{Peroxide Number}

Peroxide can accelerate the process of developing rancid odors and unpleasant taste in food. The amount of peroxide in food that is greater than 100 will be highly toxic and inedible. In a long period of time, peroxide can cause the destruction of several types of vitamins in fatty foods (eg vitamins A, C, D, E, K and small amounts of vitamin B) (Ketaren, S., 2012)

The result of peroxide number testing show that immersion $1 \times 24$ hours with nanocellulose can reduce peroxide number until $69.23 \%$ and soaking for $2 \times 24$ hours can reduce peroxide number by $57.69 \%$. Soaking used cooking oil by using nanocellulose more than 1 x 24 hours can increase the peroxide number. Figure 6 shows the results of peroxide number testing. Peroxide numbers can be reduced by the addition of nanocellulose so that used cooking oil can be reused safely because this peroxide number shows that free radicals which can cause various degenerative diseases.

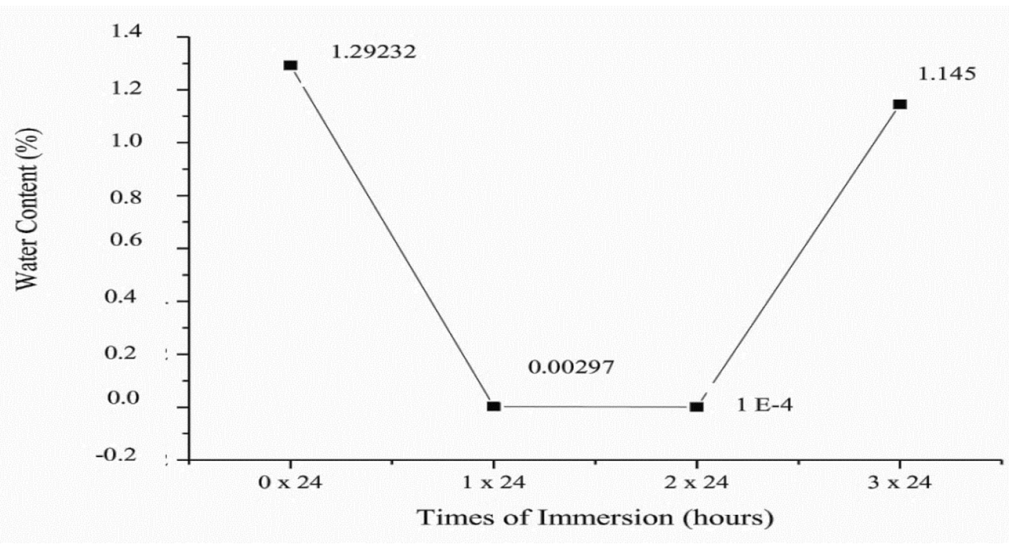

Figure 4. Water Content and Volatile Materials of Used Cooking Oil 


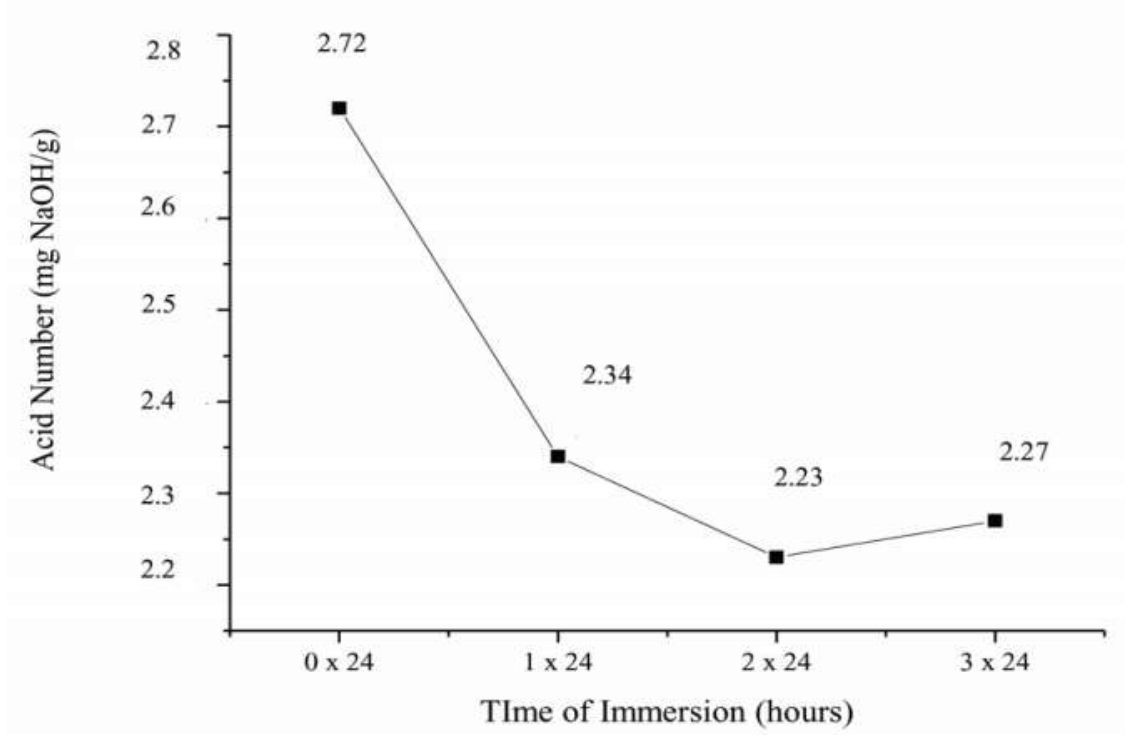

Figure 5. Free Fatty Acid or Acid Number of Used Cooking Oil

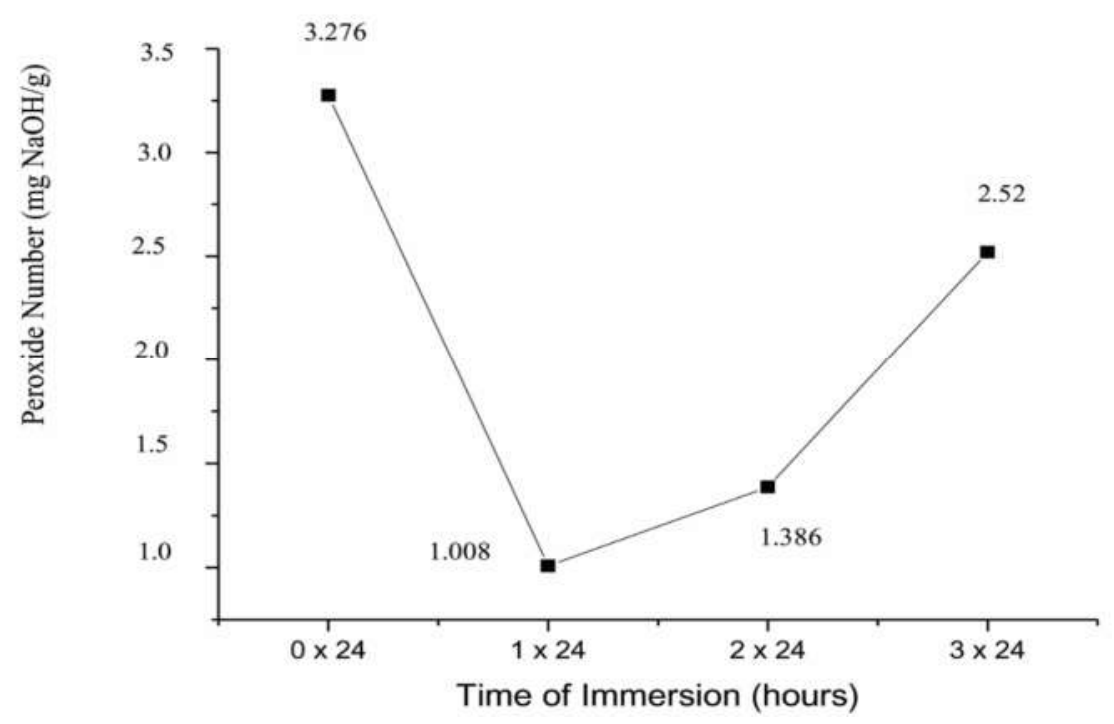

Figure 6. Peroxide Number of Used Cooking Oil

\section{CONCLUSIONS}

Based on the result of the research that has been done, nanocellulose produced from the hydrolysis process has a particle size below $500 \mathrm{~nm}$ with $95.3 \%$ at $437.5 \mathrm{~nm}$. Immersion of used cooking oil by nanocellulose for $2 \times 24$ hours can reduce the value of free fatty acids by $18.01 \%$, peroxide number decrease until $57.69 \%$ and water content decreases by $99 \%$ even though organoleptic changes do not really show. The result of this study indicate that nanocellulose has a high potential to be used as an adsorbent to increase the quality of used cooking oil.

\section{ACKNOWLEDGMENTS}

This work has supported by the Research Grant of Beginner Lecturer Research (PDP) Program under the Directorate of Higher Education, Department of National Education, The Republic of Indonesia.

\section{REFERENCES}

Badan Standardisasi Nasional. (2012). Standar Minyak Goreng Sawit, SNI 7709:2012, Jakarta

Badan Standardisasi Nasional. (2013). Standar Minyak Nabati Selain Kelapa Sawit. SNI 3741:2013, Jakarta 
Cho, M. J., \& Park, B. D. (2011). Tensile and thermal properties of nanocellulose-reinforced poly(vinyl alcohol) nanocomposites. Journal of Industrial and Engineering Chemistry, 17(1), 36-40. https://doi.org/10.1016/j.jiec.2010.10.006

Handoko, D. S. P., Triyono., Narsito., and Tutik Dwi. (2009). Peningkatan Kualitas Minyak Jelantah Menggunakan Adsorben $\mathrm{H}_{5}$-NZA dalam Reaktor Sistem Fluid Fixed Bed, 10 (2), 121-132

Ketaren, S. (2012) . Pengantar Teknologi Minyak dan Lemak Pangan, Jakarta : Penerbit Universitas Indonesia (UI-Press).

Li, W., Yue, J., \& Liu, S. (2012). Preparation of nanocrystalline cellulose via ultrasound and its reinforcement capability for poly(vinyl alcohol) composites. Ultrasonics Sonochemistry, 19(3), $479-485$. https://doi.org/10.1016/j.ultsonch.2011.11.007

Li, J., Wei, X., Wang, Q., Chen, J., Chang, G., Kong, L., $\mathrm{Su}$, J., and Liu, Y. (2012). Homogeneous isolation of nanocellulose from sugarcane bagasse by high pressure homogenization. Carbohydrate Polymers, 90, 1609-1613

Malheiro, R., Rodrigues, N., Manzke, G., Bento, A., and Pereira, J.A. (2013). The Use of Olive Leaves and Tea Extracts as Effective Antioxidants Against The Oxidation of Soybean Oil Under Microwave Heating. Industrial Crops and Products, 44, 37-43

Mancini., et al. (2015). Biological and Nutritional Properties of Palm Oil and Palmitic Acid: Effects on Health. Molecules, 20, 17339-17361.

Mandal, A., \& Chakrabarty, D. (2011). Isolation of nanocellulose from waste sugarcane bagasse (SCB) and its characterization. Carbohydrate Polymers, $86(3)$,

1291-1299. https://doi.org/10.1016/j.carbpol.2011.06.030

Mandal, A., \& Chakrabarty, D. (2014). Studies on the mechanical, thermal, morphological and barrier properties of nanocomposites based on poly(vinyl alcohol) and nanocellulose from sugarcane bagasse. Journal of Industrial and Engineering Chemistry, 20(2), 462-473. https://doi.org/10.1016/j.jiec.2013.05.003

Olivera, S., Muralidhara, H. B., Venkatesh, K., Guna, V. K., Gopalakrishna, K., \& K, Y. K. (2016). Potential
Applications of Cellulose and Chitosan Nanoparticles/composites in Wastewater Treatment: A Review. Carbohydrate Polymers. https://doi.org/10.1016/j.carbpol.2016.08.017

Peng, C. Y., Lan, C. H., Lin, P. C., \& Kuo, Y. C. (2017). Effects of cooking method, cooking oil, and food type on aldehyde emissions in cooking oil fumes. Journal of Hazardous Materials, 324, 160-167. https://doi.org/10.1016/j.jhazmat.2016.10.045

Ramdja, A.F., Febrina, L., and Krisdianto, D. (2010). Pemurnian Minyak Jelantah Menggunakan Ampas Tebu sebagai Adsorben, Jurnal Teknik Kimia, 17 (1), 7-14

Salas, C., Nypelo, T., Abreu, C.R., Carillo, C., and Rojas, O.J. (2014). Nanocellulose properties and application in colloids and interfaces, Current Opinion in Colloid \& Interface Science, 19, 383396

Suroso, A.S. (2013). Kualitas Minyak Goreng Habis Pakai Ditinjau dari Bilangan Peroksida, Bilangan Asam dan Kadar Air, Jurnal Kefarmasian Indonesia, 3(2) $77-88$

Teleken, J. G. (2016). Sugarcane Bagasse Ash For Waste Cooking Oil Treatment Applications. Biochemical Pharmacology. https://doi.org/10.1016/j.jece.2016.09.017

Venkata, R. P., \& Subramanyam, R. (2016). Evaluation of the deleterious health effects of consumption of repeatedly heated vegetable oil. Toxicology Reports, 3, 636-643. https://doi.org/10.1016/j.toxrep.2016.08.003

Wulandari, W.T., \& Dewi, R. (2018). Selulosa dari Ampas Tebu sebagai Adsorben pada Minyak Bekas Penggorengan. KOVALEN, 4(3), 332-339.

Wulandari, W.T., Rochliadi, and Arcana, I.M. (2016). Nanocellulose Prepared by Acid Hydrolysis of Isolated Cellulose from Sugarcane Bagasse. In IOP Conference Series: Materials Science and Engineering (Vol. 107, no. 1, p. 012045). IOP Publishing.

Yu Peng, C., Hang Lan, C., Chen Lin, P., and Chun Kuo, Y. (2016). Effect of Cooking Method, Cooking Oil, and Food Type on Aldehyde Emissions in Cooking Oil Fumes, Journal of Hazardous Materials, doi: http://dx.doi.org/10.1016/j.jhazmat.2016.10.045 